Religion and Gender, vol. 2, no. 2 (2012), pp.

194-206

www.religionandgender.org

URN:NBN:NL:UI:10-1-101600

ISSN: $1878-5417$

Publisher: Igitur Publishing (Utrecht)

Copyright: this work is licensed under a Creative

Commons Attribution License (3.0)

\title{
Introduction: Religion and Masculinities - Continuities and Change
}

\author{
BJÖRN KRONDORFER AND STEPHEN HUNT
}

\begin{abstract}
Author affiliation
Björn Krondorfer is Director of the Martin Springer Institute at Northern Arizona University (USA) and Endowed Professor of Religious Studies in the Department of Comparative Cultural Studies. His field of expertise is religion and gender, (post) Holocaust studies, and reconciliation studies. He is the recipient of the Norton Dodge Award for Scholarly and Creative Achievements. Publications include Male Confessions: Intimate Revelations and the Religious Imagination (Stanford), Men and Masculinities in Christianity and Judaism (London), and Remembrance and Reconciliation (Yale). Email: bjorn.krondorfer@nau.edu
\end{abstract}

Stephen Hunt is Associate Professor in the Sociology of Religion based at the University of the West of England, Bristol (UK). His research interests include religion and sexuality and the clash between religious and sexual rights. His recent publications in these areas are the edited volumes Contemporary Christianity and LGBT Sexualities and the five-volume project The Library of Essays on Sexuality and Religion (both published with Ashgate). Email: stephen3.hunt@uwe.ac.uk 
This edition of Religion and Gender embraces the subject matter of 'Religion and Masculinities: Continuities and Change.' In brief, the aim of the edition is two-fold. Firstly, to explore the interface between the broad field of men's studies (alternatively designated as masculinity studies) and the more specific field of critical men's studies in religion which engages aspects of religiosity and spirituality. Secondly, and relatedly, the theme of continuity and change denotes an exploration of maleness and masculinities in negotiating the spheres of religion by way of observable enduring constancies on the one hand, and charting elements of progressing principal trajectories on the other.

The study of masculinity and religion complicates the classic study of gender and religion insofar as it appears to remove the political edge of early feminist studies and to obfuscate the liberating potential of granting a hermeneutical privilege to social marginalization as articulated by gender theory. Restrictive gender expectations within religious traditions have done much harm to the bodies and minds of women across space and time. Whereas men's studies embrace a wide range of political agendas and disciplinary approaches, the critical study of men and religion does not shy away from enriching analysis with ethical perspectives. Where harm is inflicted, a purely descriptive-analytical approach - which, at times, may inadvertently reinforce dominant modes of the male gaze - must be complemented by the voice of the social critic who can expose the inequities written into legitimizing discourses.

\section{The State of Men's Studies}

While its roots are frequently traced back to the 1970s as a rather marginalized component of the wider remit of gender studies, men's studies and the study of masculinities can genuinely be said to have flourished with a respectable measure of independence and coherence during the first decade of the twenty-first century. Certainly, a degree of continuity is discernible in men's studies through some of its prevailing core interests in what constitutes a relatively fresh sphere of academic concern. Change is also discernible not only in its shift of focus during this brief time-line but also in the nature of the conversations circumscribing the subject matter of masculinity itself.

From a historical perspective men's studies arose from two basic but connected impetuses that have subsequently often been held in tension. Firstly, it was generated by and continues to be a positive scholarly riposte to the embryonic men's rights movement emerging from the 1970s. Secondly, in its major thrusts men's studies was encouraged by the 
feminist movement and theoretical critiques forged by the pursuits of various academic vocations.

Originally, 'men's rights' was an all-embracing term that engaged with political issues surrounding aspects of citizenship derived from reproductive rights and those of fatherhood, primarily addressing inequities that frequently reflected cultural trends in relationships and transformations in conventional family life which, in turn, attracted academic interest. Many of these issues forged the crystallization of men's organizations such as Men's Rights, Inc. and Free Men, Inc. that were both formed in 1977 as an integral part of what might be described as a social movement addressing various rights concerns. ${ }^{1}$ Simultaneously, men's studies reflected the liberating aspects engendered by so-called mythopoetic men's associations that denoted a loose collection of cadres since the early 1980s, generating a unique mode of psychological self-help and self-exploration techniques to which religiosity and spirituality readily lent itself.

Next, men' studies became subject to the gaze of scholarly enquiry (again in the early 1980s). This was evident primarily in a number of North American universities, via a rather specialized and peripheral component of gender studies programmes. In a very short time men's studies was able to establish itself in its own right as a more systematic and coordinated academic realm resultant largely from the work of scholars found in more radical circles, perhaps most notably the anti-sexist organization known as Men's Studies Task Group (MSTG). The latter aimed at a critical study of men and masculinities and included masculine studies' pioneers such as Martin Acker, Shepherd Bliss, Harry Brod, Sam Femiano, Martin Fiebert, and Michael Messner.

While it retained a rather radical edge, men's studies soon ranged further than merely reporting and analysing political issues and came to embrace and render problematic wider concerns, in particular the sociocultural constructs of masculinity. ${ }^{2}$ Perhaps predictably, in exploring such areas of masculinity from a cultural perspective, it initially took its tone from feminist critiques in analysing the impact of patriarchy, masculism, and male archetypes in the contemporary world but also digressed into historical studies. Later, it was also impacted by gay and

1 Fidelma Ashe, The New Politics of Masculinity: Men, Power and Resistance, London: Routledge 2007; Michael A. Messner, Politics of Masculinities: Men in Movements, Lanham: AltaMira Press 2000.

2 Cf. Harry Brod and Michael Kaufman (eds.), Theorizing Masculinities, London: Sage 1994. 
queer theory and their mainstay agenda of investigating the shaping of men's sexuality. Equally predictable, the radical dimension flowed from the perceived negative aspects of cultural masculinity as detrimental to men's nurturing nature. At the same time it was not beyond deconstruction of feminist theory in its perceived devaluation of men and their holistic potential. $^{3}$

Men's studies was a field of interest initially attracting a fairly narrow range of disciplines, perhaps most obviously, as already observed, in the realms of gender, sexuality, and politics. Today, however, men, masculinities, and gender are an increasingly common element of university curricula in such areas as anthropology, cultural studies, film and literature, gender studies, history, and sociology. Its adaptation to these disciplines has not been without impediments, even controversies, not least of all in the multifarious ways that they now frequently seek to reconceptualize the study of masculinities. Simultaneously, in many respects, the field can now be regarded as a truly interdisciplinary area. This reflects more than the current tendency to provide insights from various perspectives to a number of subject areas but such an approach is particularly pertinent to men's studies given its inherent complexities. ${ }^{4}$

Despite its present vibrancy, men's studies still remains an underresearched field, and this is notably so in precincts clearly related to aspects of religiosity, including religious studies, the sociology of religion, and Tteology. The major advances in these fields have invariably engaged with some extant preoccupations in the study of religiosity and have included the nature and dynamics of male authority, roles and participation in organized religion, alongside exploring gender differentiation in religious expression through the prism of masculinity.

As evinced through the contributions to this special edition, a measure of change is also discernible. More recently, men's studies has explored male spirituality in the context of masculinity and patriarchy, historical environments, lived experiences, social demographics, sexuality, and male embodiment. These almost iconic concerns clearly provoke the redirection of men's studies to reflect sociocultural change in the sphere of religiosity, particularly from its institutional base, to more privatized forms and the individualized nature of religious articulation as rendered relevant

3 Warren Farrell and James Sterba, Does Feminism Discriminate Against Men? A Debate, New York: Oxford University Press 2008; C. Hoff Sommers, The War Against Boys: How Misguided Feminism is Harming Our Young Men, New York: Simon \& Schuster 2000.

4 Cf. Todd W. Reeser, Masculinities in Theory: An Introduction, Malden, MA: WileyBlackwell 2010. 
to everyday life to which expressions of holistic spirituality gamely contribute. ${ }^{5}$

\section{Critical Men's Studies in Religion}

Power, hierarchy, privilege: these three form a deadening triad that enforces gender as a binary and static entity and presses religion into the service of legitimatization. Power proclaims and enforces gender disparity, hierarchy maintains it, and privilege denies that such disparity exists. Gender inequities have been rationalized on the grounds of both divine truth claims and scientific factuality, and religions have too often mystified and sanctified these processes. If privilege renders the beneficiaries of unjust systems blind to inequalities, one remedy may lie in the critical study of the linkages between masculinity and religion. It is imperative to open conversations about men and masculinities, on the one hand, to gender theory, feminism, and gay and queer studies and, on the other, to the multiple scholarly methodologies that analyse and interpret the religious traditions.

Ideally, such conversations are process-oriented, heterodox, nonpolemic, decentralized, historically judicious, conscious of power asymmetries, self-reflexive, committed to social repair, and respectful of the vast palette of colourful choices humans have at their disposal. Especially with respect to critical investigations in the field of masculinities and religions, questions about locality and loyalty, privilege and marginalization, and objectivity and embodiment ${ }^{6}$ should be in the centre of one's scholarly agenda. The contributors to this issue have, in their own ways, incorporated and addressed these questions.

As co-editors of 'Religion and Masculinities: Continuities and Change' we had called for contributions that are international in outlook, interdisciplinary in approach, critical in perspective, and open to methodological variety. Assuming that a globalizing world brings its own challenges to the ways that the religious traditions legitimate and defend, re-imagine and deconstruct masculinities in specific localities around the globe, we sought contributions that would gauge the extent of such continuity and change. ${ }^{7}$ What is important, it seems to us, is to engage

5 Stephen Hunt, Religion in Everyday Life, London: Routledge 2006.

6 Anne-Marie Korte, 'Openings: A Genealogical Introduction to Religion and Gender,' Religion and Gender 1:1 (2011), 9. Accessed 20 February 2012.

7 In many ways, the field of critical men's studies in religion will need to work locally and globally in parallel and intersecting ways. An excellent study demonstrating the specificity of locality in Europe is Yvonne Maria Werner (ed.), Christian Masculinity: 
with the contestations encountered by various religious traditions alongside the trajectories of new expressions of religiosity and spirituality.

While 'continuity and change' is a broad theme, it suggests that neither masculinity nor religion are stable categories but are embedded in cultural, historical, social, and political structures, no matter how supple those structures are proving to be. Do established religious authorities continue to defend hegemonic visions of masculinity in a changing world? Are sacred textual sources used to prescribe ideals of masculinity, or have they increasingly come into conflict with men's lived experiences? Are masculinities reinvigorated in fresh expressions of spiritual practices? Are male sexualities re-imagined spiritually or, to the contrary, pressed (again) into conventional forms of religiosity? How do men at the margins of heterosexuality and domination negotiate life choices within the context of religiously prescribed, conventional masculinities?

As attention shifts to men's multiple gendered identities and multiple religious belongings, diversity can be appreciated not as an obstacle but a gift. Religious and gendered diversity provides the palette of colours that saturate the surface of life with brightness, illuminate depth through shades, and create layers, contrast, and perspective. Beyond the problematic areas of power, hierarchy, and privilege, the colours of (male) gender and religion are exuberant in their beauty and vibrant in their expressiveness, at once necessary and yet gratuitous. The colours of diversity create a richness and density that cannot be reduced to functional signs and signals. They do not simply indicate, but complicate. They do not merely represent, but radiate.

Critical men's studies in religion begins at the transdisciplinary intersection of gender studies and religious studies. The important term 'critical' in this field of inquiry indicates that this project is not 'a positivist and heteronormative reading of men's presence in religious traditions but, instead, a critical reading of the privileged performances of male gender within those traditions. ${ }^{8}$ Critical men's studies in religion, then, is gender-

Men and Religion in Northern Europe in the $19^{\text {th }}$ and 20th Centuries, Leuven: Leuven University Press 2011; an example for paying attention to locality in African context is Adriaan van Klinken, 'St. Joachim as a Model of Catholic Manhood in Times of Aids: A Case Study on Masculinity in an African Christian Context,' CrossCurrents 61/4 (2011), 467-479; for global perspectives on religions and masculinities, see the CrossCurrents issue on 'Embattled Masculinities in the Religious Traditions,' ed. Björn Krondorfer (61/4, 2011).

8 Björn Krondorfer, 'Introduction,' in Björn Krondorfer (ed.), Men and Masculinities in Christianity and Judaism: A Critical Reader, London: SCM 2009, xiii. See also Joseph Gelfer, Numen, Old Men: Contemporary Masculine Spiritualities and the Problem of 
conscious, self-reflexive, deconstructionist, and transformative. Put differently, one could summarize the project in the following three points:

1) Critical men's studies in religion approaches and understands 'men' as gendered beings. With the help of gender theory, including feminist theory, men are seen within their particular gendered limitations and also in their embodiments. The fact that patriarchal gender codes have constructed men as normative and often disembodied beings is understood as a historically contingent pattern - with all the repercussions which such perception had for women and men, family and society, as well as modes of (religious/spiritual/ theological) knowing.

2) Critical men's studies in religion probes, diagnoses, and analyses. It examines how and to what extent sacred texts, traditions, experiences, and institutions have to be understood as products of men. It asks whether men, when reflecting on religion, remain caught within a sense of entitlement of male privilege or, to the contrary, whether they bring to their inquiry a sense of epistemological humility that acknowledges the limits of gendered perspectivity. What benefits, what harms are created when men remain blind to their own genderedness? What ideals, practices, and images of manliness are condoned or condemned in the religious traditions?

3) Critical men's studies in religion is transformative. It examines texts and traditions along the lines of shifts and frictions in the production of ideals of masculinity. It also is committed to exploring alternative visions of what it means to be religious as a man. Are there traces and resources in the religious traditions that resist hegemonial ideals of masculinity and help to envision other realities? Following a transformative trajectory, the critical study of men and religion opens an academic venue that does not limit itself to describing what is but envisions what may become. Scholarly inquisitiveness can enrich and reconfigure the global canvas of religious and gendered becomingness.

Patriarchy, London: Equinox 2009; Björn Krondorfer (ed.), Men's Bodies, Men's Gods: Male Identities in a (Post-)Christian Culture, New York: New York University Press 1996; Stephen Boyd, Merle Longwood, and Mark Muesse (eds.), Redeeming Men: Religion and Masculinities, Louisville: Westminster/John Know Press 1996. 


\section{Continuities and Change}

One of the overarching contributions of contemporary critical men's studies in religion is the theme of 'continuity and change'. Current studies endeavour to challenge old orthodoxies typified by deconstruction of dominant terminology such as 'world religions' hitherto prevalent in religious studies, ${ }^{9}$ by developing radical new perspectives, typified by postcolonial approaches, vital for exploring issues of locality and global dependencies. In doing so, such approaches also continue the themes of hegemony, suggesting that change and continuity are not exclusive designations. These approaches pull attention to the introspective recognition that the study of men and masculinities in relation to religion has historically been forged and developed mainly within European and US American academic environments, and that this has frequently limited the field of vision to demarcated realms of practice and belief formed within restricted cultural milieus.

Transnational and global streams create radical new tendencies and fresh possibilities. Perhaps most obviously relativizing impulses give rise to religious fundamentalism -Christian, Islamic, Jewish- in the search for certainty and assurances promised by re-envisaged pasts including the restoration of pristine and idealized gender edifices located in eulogized and exalted religious confirmations. The resurgence of fundamentalist strands of Islam, with their ambivalent attitude towards the mixed blessing of modernity including technological innovations, exemplifies such tendencies. (Inter)national impulses of the faith, and the decisive questions they raise, have merited much (often distorted) attention in the media including fanciful portrayals of Islamic attitudes towards gender. In turn, reactionary Islamic forces have not consistently eschewed innovating developments in the media such as television and the Internet in espousing its tenets of conviction in vindicating valorized gender constructs.

To be sure, colonial expansion of past centuries opened up novel configurations and potentialities as hegemonic religious formations were transported and supplanted traditional religiosity and, as extensively explored in the literature, transmogrified culture-bound indigenous gender constructs. Globalized postcolonial forces arrived in various guises but

9 Cf. Talal Asad, Genealogies of Religion: Discipline and Reasons of Power in Christianity and Islam, Baltimore: Johns Hopkins University Press 1993; Tomoko Masuzawa, The Invention of World Religions: Or, How European Universalism was Preserved in the Language of Pluralism, Chicago: University of Chicago Press 2005; Timothy Fitzgerald, The Ideology of Religious Studies, New York: Oxford University Press 2000. 
often with equally profound ramifications. While the 'clash of civilizations' thesis ${ }^{10}$ might be overestimated, the incongruity of modernizing forces on the one hand and movements of cultural defence on the other created sites of conflict and antagonism. One such site is the issue of nationhood and masculinity, in which nations are coded and imagined in gendered terms, especially in the colonial encounter. ${ }^{11}$ Another site is that of gender and contended boundaries of sexuality -exemplified by controversies over homosexuality in Christianity and Islam - which, in turn, opened up tantalizing possibilities for the academic gaze by crossing the artificial partition of men's studies and the study of sexuality.

The ebbs and flows of globalization have not been constrained to postcolonial compulsions. Simultaneously, global migration flows transform cultural reproduction and often propel the intensification of cultural-religious connections and networks across national boundaries in changing the way that migrants relate to their often alienating everyday social experiences. These migratory and minority settings lead to new configurations of masculinities, be it interracial masculinities, double discriminations (such as a confluence of Islamophobia and homophobia), or, not least, debates circumventing homonationalism(s) that currently galvanize a new generation of scholars in religion and gender in Europe and North America. ${ }^{12}$ Given the relevance and meaning of these different settings for gender, rich new sources are opened up for scholarly excavations for contemporary critical men's studies in religion.

While critical men's studies has increasingly focused the lens of enquiry to world religious traditions in international contexts, ${ }^{13}$ there have

10 Samuel P. Huntington, The Clash of Civilizations and its Making of the Social Order, New York, Simon \& Schuster 1996.

${ }^{11}$ For example, Mrinalini Sinha, Colonial Masculinity: The 'Manly Englishman' and the "Effeminate Bengali' in the Late Nineteenth Century, Manchester: Manchester University Press 1995; George Mosse, The Image of Man: The Creation of Modern Masculinity, New York: Oxford University Press 1996; for a condensed bibliography on masculinity and the nation, see Reeser, Masculinities in Theory, 196-98.

12 On interracial masculinities, see the chapter by the same title in Reeser, Masculinities in Theory; on islamophobia and homophobia, see the recently published PhD thesis by Zülfukar Çetin, Homophobie und Islamophobie: Intersektionale Diskriminierungen am Beispiel binationaler schwuler Paare in Berlin, Bielefeld: Transcript 2012; on homonationalism, see Jasbir Pua, Terrorist Assemblages: Homonationalism in Queer Times, Durham: Duke University Press Book 2007.

13 For Asia, for example, see John Powers, A Bull of Man: Images of Masculinity, Sex, and the Body in Indian Buddhism, Cambridge: Harvard University Press 2009; Charu Gupta, 'Anxious Hindu Masculinities in Colonial North India,' CrossCurrents 61/4 (2011); R. 
also been welcomed opportunities to reverse the 'telescope' and consider the intersectionality between expressions of religion and men and masculinities in the Western context. Arguably, something of an experimental spiritual revolution over the last decades of the twentieth century and those into the twenty-first century has occurred that has destabilized the categories of 'religion' and 'gender'. A whole range of innovations would seem to be a pertinent subject matter given that the decline of culturally dominant Christianity, including its conveyance of conventional masculinities, has correspondently been matched by the emergence of fresh and frequently unconventional forms of religiosity.

A prime candidate in this revolutionary spiritual thrust is what is variously called New Age, alternative or holistic spirituality, or 'inner-life' spirituality. ${ }^{14}$ These expressions of new-found spirituality threaded together disparate spiritual paths, and weaved a bricolage of interconnected idioms, images, and motifs that toyed with the boundaries of gender formation. This new spirituality has extended to expressions of Paganism (critics might say the re-invention of Paganism) which explore and manipulate dynamics of masculinity and sexuality, once again breaking down conventional concerns in men's studies.

The so designated New Spirituality has been identified by 'subjective-life forms of the sacred, which emphasise inner sources of significance and the cultivation or sacralisation of unique subjectivelives. ${ }^{15}$ Whether the New Spirituality is a meaningful widespread development is beyond our scope of discussion here. True or not, there are important implications for examining masculinity and spirituality. Subjective-life forms of the sacred are now breeding what Woodhead ${ }^{16}$ calls a 'turn to life', that is, expressions of spirituality which advance a holistic personal life. Arguably, this trend means that spirituality is not the prism through which masculinities are forged but possibly quite the opposite. This fresh field of enquiry has proved to be merely one avenue to connect with feminist studies and queer studies and consider the juxtaposition of sexual minorities and sexual diversity, all of which provide

Chopra et al. (eds.), South Asian Masculinities: Context of Change, Sites of Continuity, Dehli: Women Unlimited 2004.

${ }^{14}$ Paul Heelas, Spiritualities of Life: New Age Romanticism and Consumptive Capitalism, Oxford: Blackwell Publishing 2008.

15 Paul Heelas and Linda Woodhead, The Spiritual Revolution: Why Religion is Giving Way to Spirituality, Oxford: Blackwell 2005, 6.

16 Linda Woodhead, 'The Turn to Life in Contemporary Theology and Spirituality,' in Ursula King (ed.), Spirituality and Society in the New Millennium, Brighton: Sussex Academic Press 2001. 
scope for opening up new quarries in men's studies. These are changes which may well subvert conventional theorizing around religion, and encourage new directions as a crucial imperative in men's studies.

\section{Contributions}

Generally speaking, the contributions to this issue of Religion and Gender fall somewhere between the social-scientific oriented approaches to the study of masculinity and the field of critical men's studies in religion. The issue begins with three articles that describe, problematize, and analyse current developments around masculinity in Islam; it continues with an article on the contested visual representations of the male saviour figure of Jesus Christ, and ends with an essay on alternative trajectories of male spirituality in the male goddess movement.

The contributions of Colette Harris and Halkano Abdi Wario take us to the African context, where masculinity studies has received focused attention in the last years. ${ }^{17}$ Whereas Harris investigates masculine gender identities among both Muslim and Christian youth in Nigeria, Wario introduces the pietistic, lay-centered, missionary movement of the Tablīghi Jamā'at in Kenya. In both cases, the authors speak to male gender identityat once in flux and yet seeking stability in conventions -as it is articulated and lived in the interstices of religious ideals and practices, social norms, and cultural expectations. Caught between the opportunities of contemporary life and traditional notions of masculinity, the men described by Wario and Harris employ religion to negotiate between gender-restrictive conventions and creative expansion of such conventions. In other words, we discern how religion can operate as a constraining as much as a transformative force - and that, perhaps, makes the phenomenon of religion so effervescent, volatile, and stimulating, both as a social dynamic and an object of study.

The essay on the rejection of the homosexual orientation by the popular television host al-Qaradawi reveals a tension that currently runs through divergent interpretations of gender expectation in Islamic discourse. Read against gender theory as well as progressive and feminist voices of Muslim scholars, the authors, Scott Kugle and Stephen Hunt, conclude that the neo-traditional advocacy of intolerance of homosexuality, though popular in appeal, may not agree with Qur'anic and

17 For example, Lahoucine Ouzgane and Robert Morell (eds.), African Masculinities: Men in Africa from the Late Nineteenth Century to the Present, New York: Palgrave 2005. 
juridical sources, since the tradition of interpretations allows for greater variety regarding the acceptance of sexual minorities in Islam.

Like Kugle and Hunt, Judith Samson is concerned about the rights of sexual minorities. She shows how popular male religious images have proved to be significant on multiple levels including their adoption by sociopolitical movements. She asserts that some popular images of Jesus, especially representations of the Sacred Heart of Jesus and of Jesus as a contemporary virile male American, can be adopted as potent social contrivances in the struggle over the legitimacy of sexual minorities. Correctly noting that little has been written on popular religious images on the Internet, she excavates how Christians opposing non-heterosexuality cultivate new images to replace androgynous representations of Jesus that plausibly call into question his heterosexuality. Satiric websites criticize fundamentalist Christian's homophobia and are used to buttress versions of androgynous respectively hypermuscular images to support LGBT rights. Samson's analysis details how the images projected take their tone from capitalist Internet consumerism, while simultaneously providing an example of postmodern art that launches a technique of irony and parody. This sense of parody, the author asserts, has usurped Christianity as the grand narrative of Western culture.

Dave Green's article examines the sociological dynamics of a number of contemporary Pagan men who venerate goddesses. As a growing expression of spirituality, Paganism has proved to be particularly fruitful for masculine studies and the critical studies of men in religion. While firstwave feminism sought to study and liberate sexist versions of Christianity, the second wave began to look beyond mainstream Christianity to analyse alternative forms of religion, especially through embracing Goddess feminism, ${ }^{18}$ and around queer and gay extraction of ancient mythologies that emphasize the fluidity of gender identity and sexuality. Ethnographic research, as employed by Green, tries to get a hold of the often hidden and nebulous nature in surveying the integral Pagan practices, beliefs, and networks. Green points out that a reaction against the feminization of divinity by some Pagan men is via rooting practice within mythopoetic constructions of masculinity. Hence, the Male Goddess Movement is a counter-critique of gender essentialism; it is built around the interiorization of the female antitype as a form of liberation from the dogmas of

${ }^{18}$ Yvonne Aburrow, 'Is it Meaningful to Speak of "Queer Spirituality"? An Examination of Queer LGBT Imagery and Themes in Contemporary Paganism and Christianity,' in S. Hunt (ed.), Contemporary Christianity and LGBT Sexualities, Farnham: Ashgate 2009. 
masculinity. In this respect, ritual practice becomes of central importance to the performance of non-essentialized and enchanted forms of masculinity. 